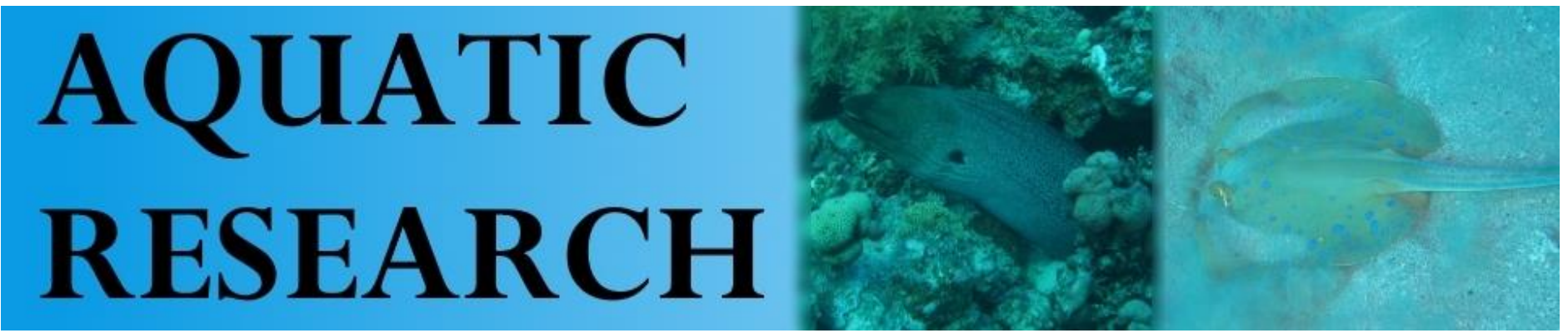

\title{
ANALYSIS OF MERCURY (HG) IN FOUR HOLOTHURIANS SPECIES (PHYLUM-ECHINODERMATA) FROM KARACHI COAST-NORTHERN ARABIAN SEA
}

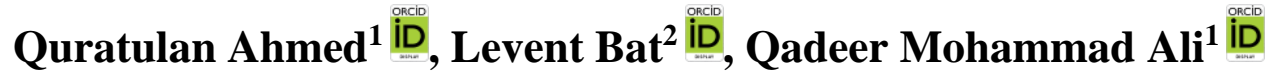

\section{Cite this article as:}

Ahmed, Q., Bat, L., Ali, Q.M. (2018). Analysis of Mercury (Hg) in Four Holothurians Species (Phylum-Echinodermata) From Karachi Coast-Northern Arabian Sea. Aquatic Research, 1(2), 55-63. DOI: 10.3153/AR18007

\section{The Marine Reference Collection and Resource Centre, University of Karachi, Karachi, 75270 Pakistan \\ ${ }^{2}$ University of Sinop, Fisheries Faculty, Department of Hydrobiology, TR57000 Sinop, Turkey.}

Submitted: 31.01 .2018

Accepted: 22.02.2018

Published online: 24.02 .2018

Correspondence:

Quratulan AHMED

E-mail:

quratulanahmed_ku@yahoo.com

\begin{abstract}
Nowadays metal bioaccumulation in holothuroids is increasing and is a cause of worry owing to toxicity. In the present study the concentrations of mercury $(\mathrm{Hg})$ were measured in holothuroids (Holothuria (Thymiosycia) arenicola Semper, 1868, Holothuria (Lessonothuria) pardalis Selenka, 1867, Holothuria (Lessonothuria) verrucosa Selenka, 1867 and Holothuria (Halodeima) atra Jaeger, 1833) collected during different seasons (pre-monsoon, monsoon, and post-monsoon) in 2015 at Buleji and Sunehri coasts of Karachi, Pakistan. Hg concentrations of tentacles were higher than those in muscle, tentacle and gut tissues of the pre-monsoon, monsoon and post-monsoon. The lowest $\mathrm{Hg}$ concentrations were found in muscle tissues at all seasons in Buleji and Sunehri coasts. The mean levels in the muscle tissues were $0.018 \mathrm{mg} / \mathrm{kg}$ dry wt. for $H$. arenicola, 0.024 $\mathrm{mg} / \mathrm{kg}$ dry wt. for $H$. verrucosa, $0.026 \mathrm{mg} / \mathrm{kg}$ dry wt. for $H$. pardalis and $0.036 \mathrm{mg} / \mathrm{kg}$ dry wt. for H. Atra. The results indicate that according to the European Union legislation the $\mathrm{Hg}$ amounts in all tissues of holothurians is much lower than permitted levels. In terms of Estimated Weekly Intakes, this current work also proved that there was no likely health hazard to consumers on account of intake of sea cucumbers under the current consumption rate in Buleji and Sunehri coasts of Karachi, Arabian Sea.
\end{abstract}

Keywords: Mercury, Holothuroids, Buleji, Sunehri, Karachi coast, Estimated Weekly Intakes, Estimated Daily Intakes, Northern Arabian Sea
๑Copyright 2018 by ScientificWebJournals Available online at

http://aquatres.scientificwebjournals.com 


\section{Introduction}

In terms of industry Karachi in Pakistan is the most important city where its coastal water is contaminated with domestic and industrial effluent. Karachi coast is impacted principally by human activities including shipyards, industrial factories, touristic and fishing activities. Therefore research on metal pollution in Karachi coasts has been increased during the recent years. Most studies have dealt with metal concentration in fish (Ahmed et al., 2014, 2015; Ahmed and Bat, 2015a,b,c,d; Ahmed and Bat, 2016a,b; Ahmed et al, 2017a) and very few study concern the holothuroids (Ahmed et al, 2017b) in Karachi coasts of the Arabian Sea. Marine organisms, especially benthic invertebrates have the ability to absorb metals from their living environment. Because of the ecological importance of holothuroids and their potential as bio-indicators, recently they are used to study heavy metal pollution. They are deposit-feeder ingesting surface sediments and feeding on detritus and associated microorganisms and well distributed in the Northern Arabian Sea (WoRMS Editorial Board, 2018). Sea cucumbers also were accepted as biomonitor organisms (Warnau et al., 2006).

Heavy metals are considered the important chemicals in marine environments, and since they are not biodegradable, they can accumulate at the top of the food chain. Many inorganic elements that are non-essential for people enter the diet via seafood. Indeed, most of them are present in aquatic environment, usually in trace amounts that may be toxic under certain conditions. One of the most important non-essential inorganic elements in seafood that have no known or accepted biological function in organisms is mercury. $\mathrm{Hg}$ is very toxic metal and its harmful effects are well documented. Most inorganic $\mathrm{Hg}$ compounds are toxic, but organic $\mathrm{Hg}$ compounds, formed when $\mathrm{Hg}$ compounds combine with certain organic molecules, are even more so. These organic $\mathrm{Hg}$ compounds are soluble in fat, which means they accumulate easily in the body and so penetrate readily into the nerves and brain. $\mathrm{Hg}$ occurs naturally in marine environment and can also be released into the air thanks to industrial pollution. It vapour is easily transported in the atmosphere and falls from the air and can pile up in the aquatic environment (Bat and Özkan, 2015).

Seafood is a good source of nutrition. It is high in protein, vitamin B and good fatty acids as omega 3 . The health benefits of eating seafood outweigh the potential risks. $\mathrm{Hg}$ is a contaminant that can be found in edible tissues. $\mathrm{Hg}$ amounts differ from coasts to other coasts and may be owing to human activities or to natural causes. $\mathrm{Hg}$ poisoning is generally counted as the maximum extensive environmental health threat and its absorption may constitute a serious risk to human health. It is well known that in Minimata, Japan, hundreds people died or became very heavily sick mostly from nervous system damage from eating seafood from coastal waters that were seriously contaminated with $\mathrm{Hg}$ from local industrial discharge.

Sea cucumbers are a pretty appraised as food in the very Asian countries. They are traditionally eaten up raw, dried, boiled (Özer et al., 2004), soups and salads (Jinadasa et al., 2014) as food for human consumption. Moreover they are considered to be a high medical value (Jinadasa et al., 2014). The current study aims to determine the concentrations of mercury $(\mathrm{Hg})$ in muscle, tentacle and gut tissues of holothuroids Holothuria (Thymiosycia) arenicola Semper, 1868, Holothuria (Lessonothuria) pardalis Selenka, 1867, Holothuria (Lessonothuria) verrucosa Selenka, 1867 and Holothuria (Halodeima) atra Jaeger, 1833 collected during different seasons (pre-monsoon, monsoon, post-monsoon) in 2015 at Buleji and Sunehri coasts of Karachi, Pakistan to compare the results with those obtained in international regulations and to assess the potential health risk for consumers based on their intake.

\section{Materials and Methods}

A total of 144 specimens namely $H$. arenicola, $H$. pardalis, $H$. verrucosa and $H$. atra (6 individuals in each species and 6 individuals each season) were collected from Buleji and Sunehri coasts of Karachi in 2015 (Figure 1). After collection, individuals were put in seawater from the sampling stations and transferred to the laboratory. The muscle, tentacle and gut tissues of holothuroids were then separated carefully (modified from Bernhard 1976; UNEP 1984 and 1985). 5 grams of muscles, whole tentacles and whole gut of each sea cucumber samples were placed into the crucibles and were dried in furnace at $600^{\circ} \mathrm{C}$ temperature for 3 hours and then dry ash were weighted in digital balance. These ashes were digested in the flasks containing $10 \mathrm{ml}$ of concentrated $\mathrm{HCl}$. When the digestions were completed, the solutions were cooled to ambient temperature and the digest was filtered and made up to $100 \mathrm{ml}$ in a volumetric flask using ultrapure water as the diluent. The analysis for total mercury was performed on Mercury Hydride system (cold vapor Technique) Atomic Absorption Spectrometer. The AA Analyst 700 atomic absorption spectrometer with 253.7 wavelengths was used to determine $\mathrm{Hg}$ concentration. Detection limit was $2 \mathrm{ng} \mathrm{Hg}(0.00004 \mathrm{mg} / \mathrm{L}$ in a $50 \mathrm{~mL}$ sample). 


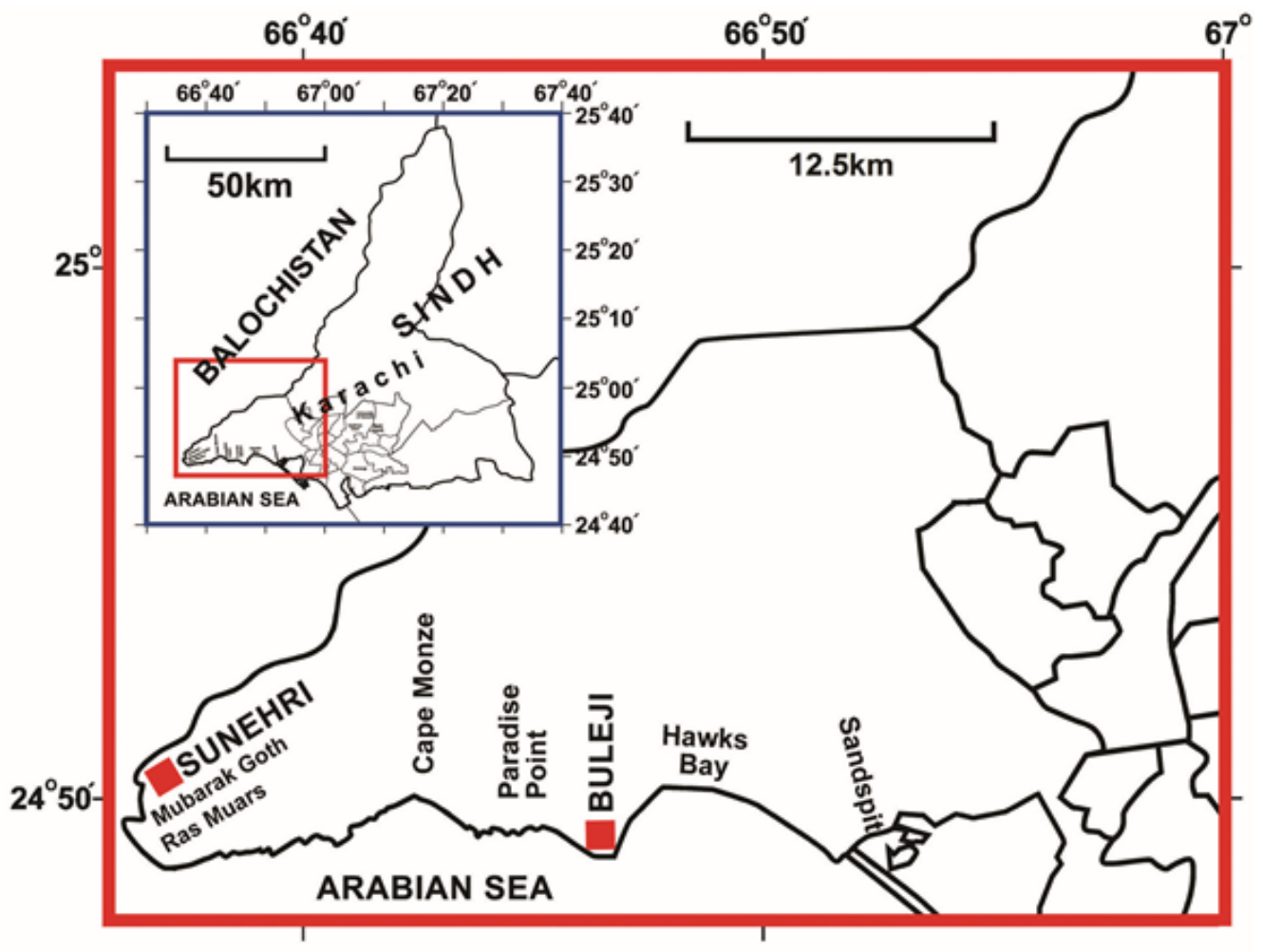

Figure 1. Sampling area from Buleji and Sunehri coasts of Karachi, Arabian Sea

\section{Intake Levels Calculation}

The weekly intake amounts were calculated using the highest $\mathrm{Hg}$ concentration in sea cucumbers EWI (Estimated Weekly Intakes $)=$ the highest concentration of $\mathrm{Hg}(\mathrm{mg} / \mathrm{kg})$ multiplied by holothuroids consumption $(\mathrm{kg} / 70 \mathrm{~kg}$ body $\mathrm{wt}$. /week).

\section{Statistical Analysis}

Mean values of residues of $\mathrm{Hg}$ among sample locations of the holothuroids were compared using one-way analysis of variance (ANOVA) following Tukey post hoc comparisons (Zar, 1984). P-values less than 0.05 were considered significant. All analysis was carried out using the SPSS, version 21 and Excel 2010 to analyses the influence of pre-monsoon, monsoon and post-monsoon. All values were being expressed on $\mathrm{mg} / \mathrm{kg}$ dry wt. basis.

\section{Results and Discussion}

The concentrations of $\mathrm{Hg}$ in muscle, tentacles and gut samples of the holothuroids are presented in Figures 2-5. $\mathrm{Hg}$ concentrations of tentacles were higher than those in muscle, tentacle and gut tissues of the pre-monsoon, monsoon and post-monsoon as the differences were significant $(\mathrm{P}<0.05)$, except in $H$. verrucosa from Buleji coasts in premonsoon as the difference was not significant $(\mathrm{P}>0.05)$. The mean $\mathrm{Hg}$ levels in tentacles of $H$. verrucosa, $H$. arenicola, $H$. atra and $H$. pardalis were $0.077,0.126,0.127$ and 0.170 mg / kg dry wt., respectively. However the mean $\mathrm{Hg}$ levels in gut of $H$. verrucosa, $H$. arenicola, $H$. atra and $H$. pardalis were $0.047,0.029,0.059$ and $0.049 \mathrm{mg} / \mathrm{kg}$ dry wt., respectively. The lowest $\mathrm{Hg}$ concentrations were found in muscle tissues at all seasons in Buleji and Sunehri coasts. The concentrations of $\mathrm{Hg}$ also showed significant differences according to the sampling stations. The highest $\mathrm{Hg}$ concentrations in gut of $H$. arenicola and $H$. pardalis were usually observed in pre-monsoon and monsoon at Sunehri coasts. $\mathrm{Hg}$ levels were not constant in muscle, tentacle and gut tissues during pre-monsoon, monsoon and post-monsoon at both Buleji and Sunehri coasts. The sampling stations with the highest and lowest $\mathrm{Hg}$ levels varied according to the sampling periods and tissues. 
$\square$ Muscles $\quad \square$ Tentacles $\quad$ Gut

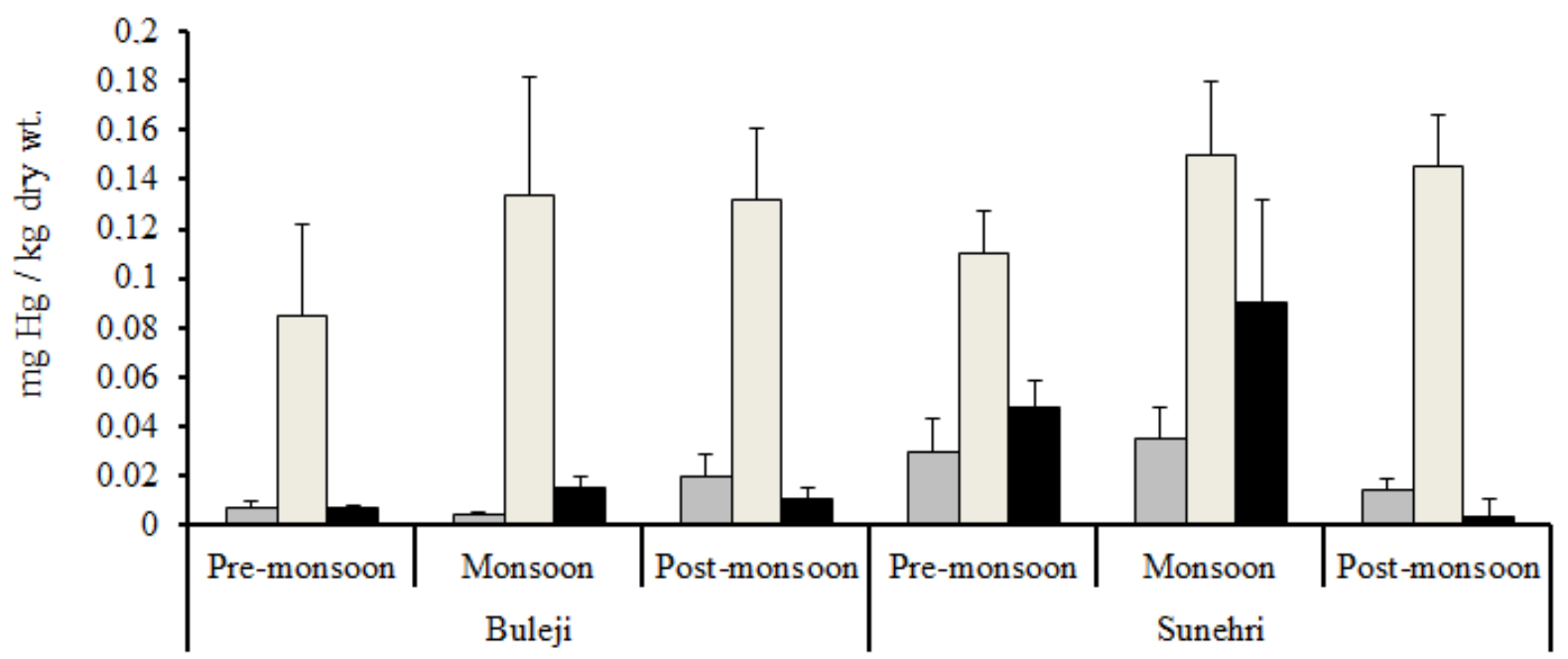

Figure 2. The means with standard errors (vertical lines) of $\mathrm{Hg}$ concentrations ( $\mathrm{mg} / \mathrm{kg}$ dry wt.) in muscle, tentacles and gut tissues of $H$. arenicola from Buleji and Sunehri coasts of Karachi, Arabian Sea.

$\square$ Muscles $\quad \square$ Tentacles $\quad$ Gut

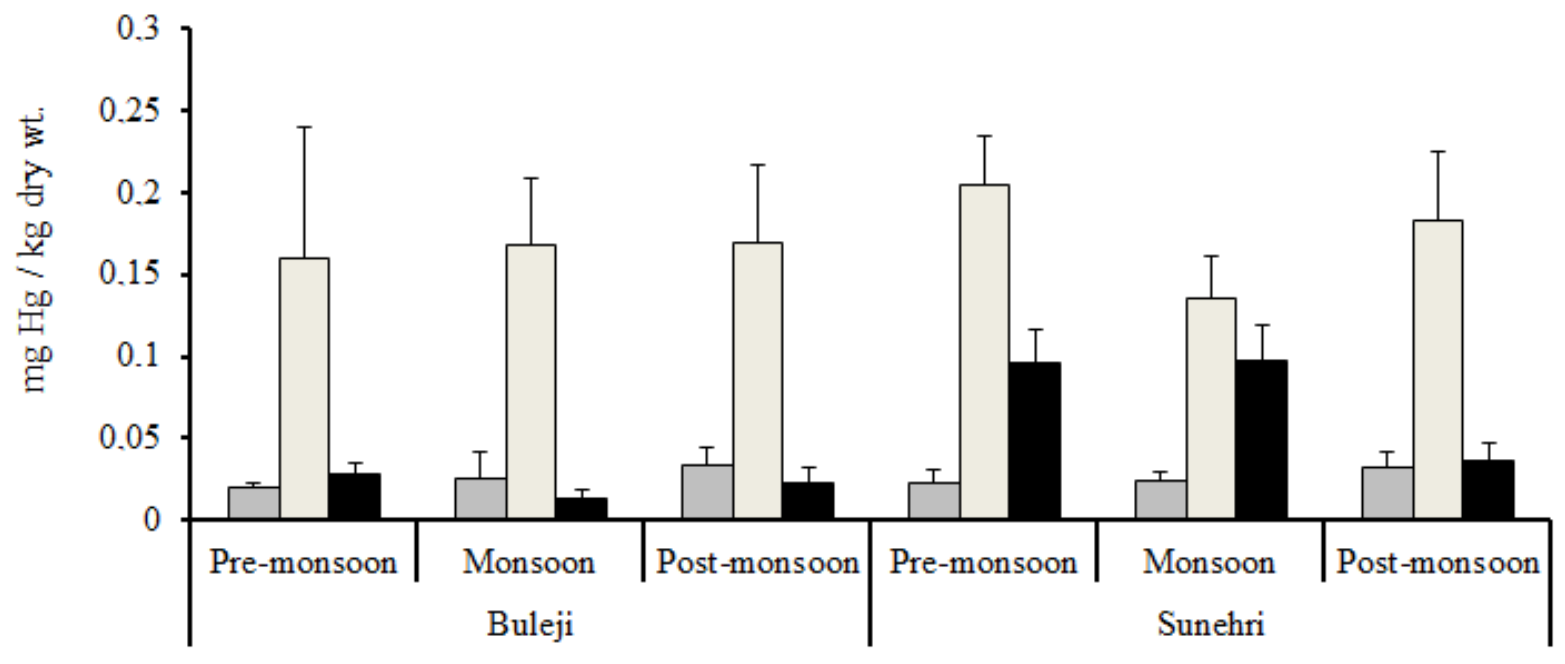

Figure 3. The means with standard errors (vertical lines) of $\mathrm{Hg}$ concentrations (mg/kg dry wt.) in muscle, tentacles and gut tissues of $H$. pardalis from Buleji and Sunehri coasts of Karachi, Arabian Sea. 


\section{$\square$ Muscles $\quad \square$ Tentacles $\quad$ Gut}

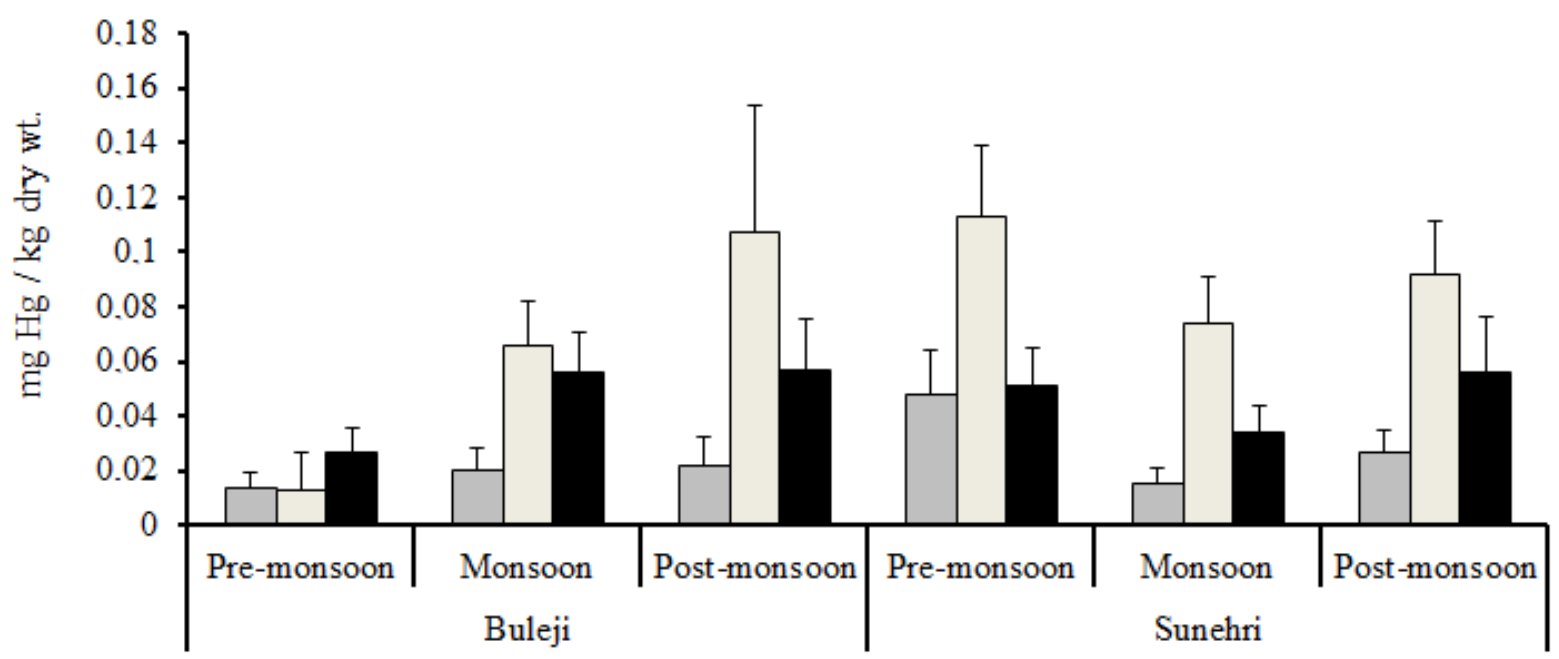

Figure 4. The means with standard errors (vertical lines) of $\mathrm{Hg}$ concentrations ( $\mathrm{mg} / \mathrm{kg}$ dry wt.) in muscle, tentacles and gut tissues of $H$. verrucosa from Buleji and Sunehri coasts of Karachi, Arabian Sea.

$\square$ Muscles $\square$ Tentacles $\quad$ Gut

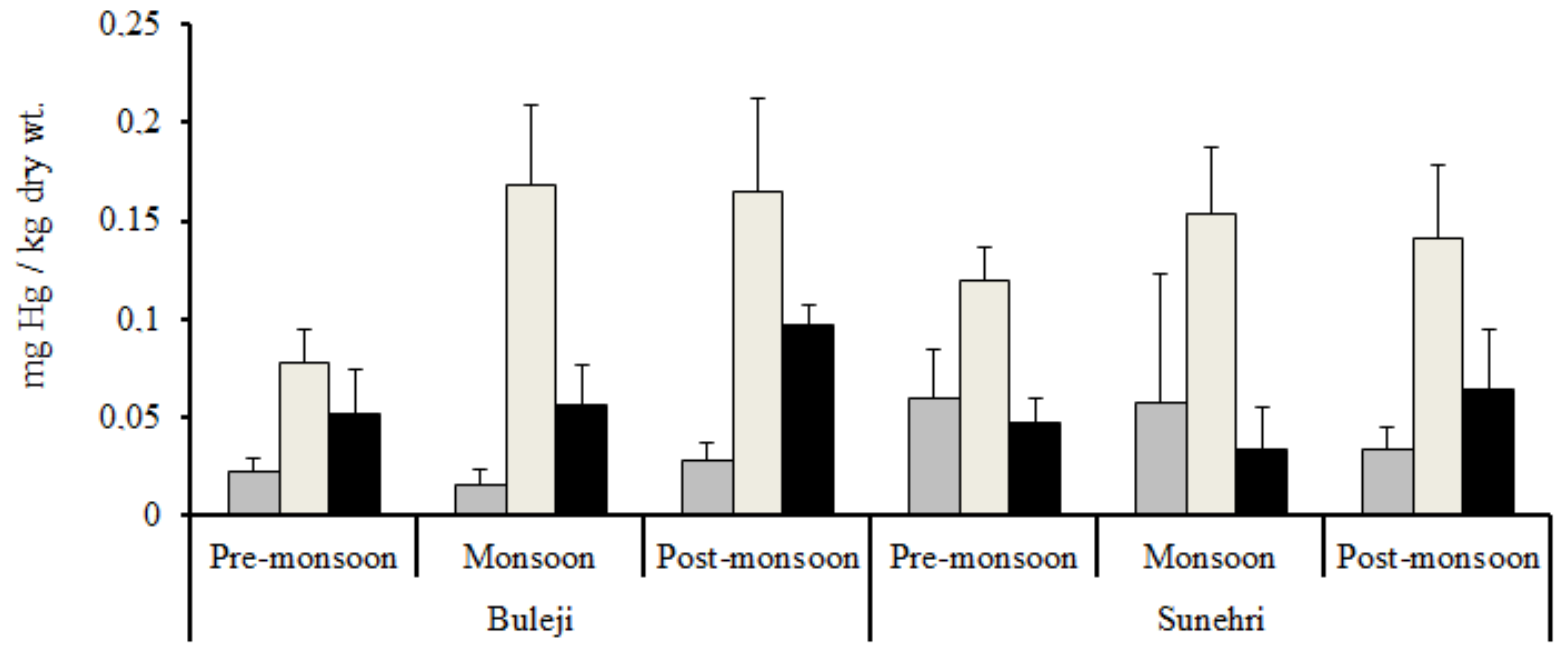

Figure 5. The means with standard errors (vertical lines) of $\mathrm{Hg}$ concentrations (mg/kg dry wt.) in muscle, tentacles and gut tissues of $H$. atra from Buleji and Sunehri coasts of Karachi, Arabian Sea. 
In the current work statistical analysis of the data displayed significant differences $(\mathrm{P}<0.05)$ among all of the holothuroids. The mean residue amounts of $\mathrm{Hg}$ varied amongst all species. The $\mathrm{Hg}$ concentrations ( $\mathrm{mg} / \mathrm{kg}$ dry weight) in muscle tissues of the sampled holothuroids are as follows: $H$. arenicola $(0.018 \mathrm{mg} / \mathrm{kg}$ dry wt. $)<H$. verrucosa $(0.024$ $\mathrm{mg} / \mathrm{kg}$ dry wt. $)<H$. pardalis $(0.026 \mathrm{mg} / \mathrm{kg}$ dry wt. $)<H$. atra $(0.036 \mathrm{mg} / \mathrm{kg})$. Means of $\mathrm{Hg}$ in muscles of holothuroids are much lower than the maximum permissible limit $(0.5$ $\mathrm{mg} / \mathrm{kg}$ wet wt.) set by the European Union and Turkish Food Codex (EU Commission Regulations, 2001 and 2006; TFC, 2002 and 2008). Environmental Quality Standards (EQS) for $\mathrm{Hg}$ in biota is given in European Union legislative acts as $0.02 \mathrm{mg} / \mathrm{kg}$ wet wt. (Official Journal of the European Union, 2013; European Union, 2014). Since our results were given in dry wt., mean concentrations of $\mathrm{Hg}$ converted to wet wt. dividing by 8.0 as factor. It was calculated that overall means of $\mathrm{Hg}$ in muscle tissues were between 4.4 and 9 times lower than EQS value $(0.02 \mathrm{mg} / \mathrm{kg}$ wet wt.).

In the literature, $\mathrm{Hg}$ levels in the tissues of the holothuroids vary considerably among different studies. The obtained data illustrated that mean $\mathrm{Hg}$ accumulation in $H$. atra that is similar to Jinadasa et al. (2014) who found that the mean concentration was $0.031( \pm 0.013) \mathrm{mg} / \mathrm{kg}$ dry wt. from North-Western Sea of Sri Lanka. The study of Jinadasa et al. (2014) from North-Western Sea of Sri Lanka indicated that $\mathrm{Hg}$ levels in ten Holothurians species ranged from 0.025 to $0.446 \mathrm{mg} / \mathrm{kg}$ dry wt., which is higher than those in the values detected in our study.

Holothuroids are deposit-feeders and live in close association with sediment, and feeds mainly detrital particles and associated microorganisms (WoRMS Editorial Board, 2018). Many studies (Bat et al., 2015 and 2017; Bat and
Özkan, 2015) indicated that heavy metals including $\mathrm{Hg}$ tend to accumulate in sediment. It is surprising that $H$. arenicola, $H$. pardalis, $H$. verrucosa and $H$. atra, which are benthic species and are associated with sediment, did not show the high levels of $\mathrm{Hg}$. These results confirm that the both Buleji and Sunehri coasts of Karachi are not seriously contaminated with $\mathrm{Hg}$. Slight differences in $\mathrm{Hg}$ levels in these holothuroids could considerably be attributed to the differences in seasons. It may be suggested that seasonal changes play basic and significant role in the control of $\mathrm{Hg}$ accumulation.

$\mathrm{Hg}$ is a non-essential element that can be toxic and carcinogenic at even low concentration and is known has no role in biological processes in living organisms. The European Food Safety Authority's revised the provisional tolerable weekly intake (PTWI) of inorganic Hg and set a PTWI of $0.004 \mathrm{mg} / \mathrm{kg}$ body wt. applies to seafood (EFSA, 2012). Special attention to well-being hazard, the permissible weekly intakes was computed by means of references for edible tissues of sea cucumbers eaten up by public. Pursuant to Food and Agriculture Organization (FAO) counts of seafood consumption in Pakistan remarked that the adult person eats the mean daily seafood consumption in Pakistan is $5 \mathrm{~g}$ per person (FAO, 2010), which is well-matched to 35 $\mathrm{g} /$ week. The tolerable weekly intake of elements as PTWI (Provisional Tolerable Weekly Intake), are set by the Food and Agriculture Organization/World Health Organization (FAO/WHO) Joint Expert Committee on Food Additives (JECFA). PTWI is the greatest of a pollutant to which a person can be exposed per week over a lifetime without an unacceptable risk of health effects (WHO, 1989 and 1996). Estimated Weekly Intake (EWI) and Estimated Daily Intake (EDI) for a $70 \mathrm{~kg}$ body weight of an adult person on basis of the current work outcomes were given in Table 1.

Table 1 Estimated Weekly Intakes (EWI) and Estimated Daily Intakes (EDI) of $\mathrm{Hg}$ as $\mathrm{mg} / \mathrm{kg}$ wet wt. in edible tissues of holothuroids from Buleji and Sunehri coasts of Karachi, Arabian Sea.

\begin{tabular}{|c|c|c|c|c|c|c|c|}
\hline \multirow{2}{*}{ Species } & \multirow{2}{*}{ PTWI $^{\mathbf{a}}$} & \multirow{2}{*}{ PTWI $^{b}$} & \multirow{2}{*}{ PTDI $^{\mathrm{c}}$} & \multicolumn{2}{|c|}{ EWI $^{d}$} & \multicolumn{2}{|c|}{$\mathbf{E D I}^{\mathrm{e}}$} \\
\hline & & & & Buleji & Sunehri & Buleji & Sunehri \\
\hline H. arenicola & 0.004 & 0.28 & 0.04 & 0.0021 & 0.0030 & 0.00030 & 0.00045 \\
\hline H. pardalis & 0.004 & 0.28 & 0.04 & 0.0028 & 0.0026 & 0.00040 & 0.00038 \\
\hline H. verrucosa & 0.004 & 0.28 & 0.04 & 0.0023 & 0.0402 & 0.00033 & 0.00060 \\
\hline H. atra & 0.004 & 0.28 & 0.04 & 0.0025 & 0.0039 & 0.00035 & 0.00055 \\
\hline \multicolumn{8}{|c|}{$\begin{array}{l}\text { aPTWI (Provisional Tolerable Weekly Intake) in mg/week/kg body wt. } \\
\text { bPTWI for } 70 \mathrm{~kg} \text { adult person (mg/week/70 kg body wt.) } \\
\text { cPTDI (Permissible Tolerable Daily Intake) (mg/day/70 kg body wt.) } \\
\text { dEWI (Estimated Weekly Intake) (mg/week/ kg body wt.) } \\
{ }^{\text {e} E D I ~(E s t i m a t e d ~ D a i l y ~ I n t a k e) ~(m g / d a y / ~ k g ~ b o d y ~ w t .) ~}\end{array}$} \\
\hline
\end{tabular}


From the people health point of sight, this current work proved that there was no likely health hazard to consumers on account of intake of sea cucumbers under the current consumption rate in Buleji and Sunehri coasts of Karachi, Arabian Sea.

$\mathrm{Hg}$ is consistent element in the marine ecosystem giving rise to grave disease in biota and human. Sources of $\mathrm{Hg}$ for marine water include atmospheric deposition, straight and via runoff, as well as direct discharges into seashores. Much of the $\mathrm{Hg}$ added to marine ecosystem accumulates in sediments where it has a risk to benthic biota and to people via consumption of these species. Sea cucumbers are much consumed seafood in the Asian countries (Özer et al., 2004), and they are good biomonitors for measurement the impacts of different environmental chemicals on marine ecosystem. However results of current work revealed that $\mathrm{Hg}$ amounts in the edible tissues were below the highest tolerable limits.

\section{Conclusions}

The outcomes of the current work are not detected health risk for the human population through seafood consumption. $\mathrm{Hg}$ in muscles of holothuroids are much lower than the maximum permissible limit $(0.5 \mathrm{mg} / \mathrm{kg}$ wet wt.) set by the International Food Codex. Further investigates are needed to adequately evaluate mean amounts and the variability of $\mathrm{Hg}$ and other toxic elements in Pakistan food. It is also needed to determine the toxicological effects of non-essential metals on these congeners. Furthermore, the $\mathrm{Hg}$ also toxic a lifespan cancer risk to consumers of seafood collected from the Arabian Sea. Thus, continuous monitoring of heavy metal pollutants is needed to mitigate the impact of these contaminants on people health and the marine ecosystem.

\section{Conflict of Interest Statement}

We declare that we have no conflict of interest.

\section{References}

Ahmed, Q., Bat, L., Mohammed Ali, Q. (2014). Determination of $\mathrm{Fe}, \mathrm{Zn}, \mathrm{Mn}, \mathrm{Cu}, \mathrm{Cd}$ and $\mathrm{Pb}$ concentrations in Scatophagus argus (Linnaeus, 1766) from the Korangi fish harbour, Karachi, Pakistan. Pakistan Journal of Marine Sciences, 23 (1\&2), 25-32.

Ahmed, Q., Bat, L., Yousuf, F. (2015). Accumulation of heavy metals in tissues of long tail tuna from Karachi Fish
Harbour, Pakistan. Aquatic Science and Technology, 3(1), 103-115.

Ahmed, Q., Bat, L. (2015a). Heavy metal levels in Euthynnus affinis (Cantor, 1849) Kawakawa fish marketed of Karachi fish harbour, Pakistan and potential risk of human health. J. Black Sea/Mediterranean Environment, 21(1), 35-44.

Ahmed, Q., Bat, L. (2015b). Mercury (Hg) Levels in Indian mackerel Rastrelliger kanagurta (Scombridae) from Karachi fish harbour and its risk assessment. Journal of FisheriesSciences.com, 9(3), 15-19.

Ahmed, Q., Bat, L. (2015c). Potential risk of some heavy metals in Pampus chinensis (Euphrasen) Chinese silver pomfret Stromateidae collected from Karachi fish harbour, Pakistan. International Journal of Marine Science, 5(21), 15.

Ahmed, Q., Bat, L. (2015d). Comparison of Pb and Cd concentration in tissues of fish Alepes djedaba (Forsskål, 1775) collected from Karachi fish harbour. International Journal of Fauna and Biological Studies, 2(4), 93-96.

Ahmed, Q., Bat, L. (2016a). The role of $\mathrm{Zn}$ and $\mathrm{Cu}$ in muscles tissues of Pampus argenteus (Euphrasen, 1788), marketed by Karachi fish harbour, Pakistan. Walailak Journal of Science and Technology, 13(7), 571-578.

Ahmed, Q., Bat, L. (2016b). Levels and health risk assessments of $\mathrm{Cd}$ and $\mathrm{Pb}$ in Pomadasys maculatus marketed by Karachi fish harbor. ILMU KELAUTAN: Indonesian Journal of Marine Sciences, 21(2), 53-58.

Ahmed, Q., Bat, L., Yousuf, F. (2017a). Contamination of $\mathrm{Cu}, \mathrm{Zn}, \mathrm{Fe}$ and $\mathrm{Mn}$ in Katsuwonus pelamis (Linnaeus, 1758) from Karachi fish harbor and potential risks to human health. International Journal of Marine Science, 7(9), 7687.

Ahmed, Q., Mohammed Ali, Q., Bat, L. (2017b). Assessment of heavy metals concentration in Holothurians, sediments and water samples from coastal areas of Pakistan (northern Arabian Sea). Journal of Coastal Life Medicine, 5(5), 191-201.

Bat, L., Özkan, E.Y., Öztekin, H.C. (2015). The contamination status of trace metals in Sinop coast of the 
Black Sea, Turkey. Caspian Journal of Environmental Sciences, 13(1), 1-10.

Bat, L., Özkan, E.Y. (2015). Chapter 13. Heavy metal levels in sediment of the Turkish Black Sea coast. In: Bikarska I, Raykov V, Nikolov N. (Eds.) Progressive Engineering Practices in Marine Resource Management (p. 399-419) Advances in Environmental Engineering and Green Technologies IGI Global book series USA. ISSN 23269162

Bat, L., Özkan, E.Y., Büyükisik, H.B., Öztekin, H.C. (2017). Assessment of metal pollution in sediments along Sinop peninsula of the Black Sea. International Journal of Marine Science, 7(22), 205-213.

Bernhard, M. (1976). Manual of Methods in the Aquatic Environment Research. FAO Fisheries Technical Paper FIRI/T no.158, Food and Agriculture Organisation, Rome.

EC (COMMISSION REGULATION) No 466/2001 of 8 March 2001 setting maximum levels for certain contaminants in foodstuffs. Retrieved from https://assurance.redtractor.org.uk/contentfiles/Farmers5441.pdf? $=635912156334316244($ accessed 29.01.18)

EC (COMMISSION REGULATION) No 1881/2006 of 19 December 2006 setting maximum levels for certain contaminants in foodstuffs. Retrieved from https://www.fsai.ie/uploadedFiles/Consol_Reg1881_2006. pdf (accessed 29.01.18)

EFSA Panel on Contaminants in the Food Chain (CONTAM). (2012). Scientific opinion on the risk for public health related to the presence of mercury and methylmercury in food. EFSA Journal, 10(12), 2985-3226.

European Union (2014). Common implementation strategy for the water framework directive (2000/60/EC) Guidance, Document No. 32 on biota monitoring (the implementation of $\left.\mathrm{EQS}_{\text {biota }}\right)$ under the water framework directive. EU Technical Report - 2014 - 083, Publication Office, 87 pp. Retrieved from https://circabc.europa.eu/sd/a/62343f10$\underline{5759-4 \mathrm{e} 7 \mathrm{c}-\mathrm{ae} 2 \mathrm{~b}-}$

12677aa57605/Guidance\%20No\%2032\%20-

\%20Biota\%20Monitoring.pdf (accessed 29.01.18)

FAO. 2010. Statistics Division Food Security Statistics, Food Consumption. Retrieved from https://www.google.com.tr/search?ei=229vWoCSLsXXw
AK61ZeQAg\&q=FoodConsumptionFoodGroups en\&oq= FoodConsumptionFoodGroups_en \&gs_l=psyab.3..109594.109594.0.110467.1.1.0.0.0.0.0.0..0.0...0...1c 1.64.psy-ab..1.0.0....0.LsEWLycb_ho

(accessed 29.01.18)

Jinadasa, B.K.K.K., Samanthi, R.I., Wicramsinghe, I. (2014). Trace metal accumulation in tissue of sea cucumber species; North-Western Sea of Sri Lanka. American Journal of Public Health Research, 2(5A), 1-5.

Official Journal of the European Union (2013). Directive 2013/39/EU of the European Parliament and of the Council of 12 August 2013 amending Directives 2000/60/EC and 2008/105/EC as regards priority substances in the field of water policy. L 226:1-17. Retrieved from http://eurlex.europa.eu/legal-

content/EN/TXT/PDF/?uri=CELEX:32013L0039\&from=E $\underline{\mathrm{N}}$ (accessed 29.01.18)

Özer, N.P., Mol, S., Varlık, C. (2004). Effect of the handling procedures on the chemical composition of sea cucumber. Turkish Journal of Fisheries and Aquatic Sciences, 4, 7174.

TFC (2002). Official Gazette of Republic of Turkey. Notifications about determination of the maximum levels for certain contaminants in foodstuffs of Turkish Food Codex (in Turkish). (Notification No: 2002/63), Issue: $24885 . \quad$ Retrieved from http://www.resmigazete.gov.tr/main.aspx?home=http://ww w.resmigazete.gov.tr/eskiler/2002/09/20020923.htm/20020 923.htm\&main=http://www.resmigazete.gov.tr/eskiler/200 2/09/20020923.htm (accessed 29.01.18)

TFC (2008). Official Gazette of Republic of Turkey. Notifications about maximum levels for certain contaminants in foodstuffs (in Turkish). No 2008 / 26, Issue: Retrieved from http://www.resmigazete.gov.tr/main.aspx?home=http://ww w.resmigazete.gov.tr/eskiler/2008/05/20080517.htm/20080 517.htm\&main=http://www.resmigazete.gov.tr/eskiler/200 8/05/20080517.htm (accessed 29.01.18)

UNEP (1984). Determination of Total $C d, \mathrm{Zn}, \mathrm{Pb}$ and $\mathrm{Cu}$ in Selected Marine Organisms by flameless AAS. Reference Methods for Marine Pollution Studies, 11 Rev 1. 
UNEP (1985). GESAMP: Cadmium, lead and tin the Marine Environment. UNEP Regional Seas Reports and Studies, no 56, GESAMP Reports and Studies, no 22.

Warnau, M., Dutrieux, S., Ledent, G., Rodriguez Y Baena, A.M., Dúbois, P. (2006). Heavy metals in the sea cucumber Holothuria tubulosa (Echinodermata) from the Mediterranean Posidonia oceanica ecosystem: body compartment, seasonal, geographical and bathymetric variations. Environmental Bioindicators, 1, 1-18.

WHO (World Health Organization) (1989). Heavy metals environmental aspects. Environmental Health Criteria, No. 85 Geneva, Switzerland.
WHO (World Health Organization). (1996). Trace elements in human nutrition and health. NLM Classification, QU 130, Geneva, Switzerland. ISBN 9241561734

WoRMS Editorial Board (2018). World Register of Marine Species. Retrieved from http://www.marinespecies.org at VLIZ. doi:10.14284/170 (accessed 29.01.18)

Zar, J.H. (1984). Biostatistical analysis. Second edition. Prentice Hall, Int., New Jersey. 